\title{
LAKOTA AMERICA
}




\section{THE LAMAR SERIES IN WESTERN HISTORY}

The Lamar Series in Western History includes scholarly books of general public interest that enhance the understanding of human affairs in the American West and contribute to a wider understanding of the West's significance in the political, social, and cultural life of America. Comprising works of the highest quality, the series aims to increase the range and vitality of Western American history, focusing on frontier places and people, Indian and ethnic communities, the urban West and the environment, and the art and illustrated history of the American West.

\section{EDITORIAL BOARD}

Howard R. Lamar, Sterling Professor of History Emeritus, Past President of Yale University

William J. Cronon, University of Wisconsin-Madison

Philip J. Deloria, Harvard University

John Mack Faragher, Yale University

Jay Gitlin, Yale University

George A. Miles, Beinecke Library, Yale University

Martha A. Sandweiss, Princeton University

Virginia J. Scharff, University of New Mexico

Robert M. Utley, Former Chief Historian, National Park Service

\section{RECENT TITLES}

George I. Sánchez: The Long Fight for Mexican American Integration, by Carlos K. Blanton

White Fox and Icy Seas in the Western Arctic: The Fur Trade, Transportation, and Change in the Early Twentieth Century, by John R. Bockstoce

Growing Up with the Country: Family, Race, and Nation after the Civil War, by Kendra Taira Field

Grounds for Dreaming: Mexican Americans, Mexican Immigrants, and the California Farmworker Movement, by Lori A. Flores

Lakota America: A New History of Indigenous Power, by Pekka Hämäläinen

The American West: A New Interpretive History, Second Edition, by Robert V. Hine, John Mack Faragher, and Jon T. Coleman

Legal Codes and Talking Trees: Indigenous Women's Sovereignty in the Sonoran and Puget Sound Borderlands, 1854-1946, by Katrina Jagodinsky

Gathering Together: The Shawnee People through Diaspora and Nationhood, 1600-1870, by Sami Lakomäki

An American Genocide: The United States and the California Indian Catastrophe, 1846-1873, by Benjamin Madley

Frontiers in the Gilded Age: Adventure, Capitalism, and Dispossession from Southern

Africa to the U.S.-Mexican Borderlands, 1880-1917, by Andrew Offenburger

Home Rule: Households, Manhood, and National Expansion on the Eighteenth-Century Kentucky Frontier, by Honor Sachs

The Cherokee Diaspora: An Indigenous History of Migration, Resettlement, and Identity, by Gregory D. Smithers

First Impressions: A Reader's Journey to Iconic Places of the American Southwest,

by David J. Weber and William deBuys 

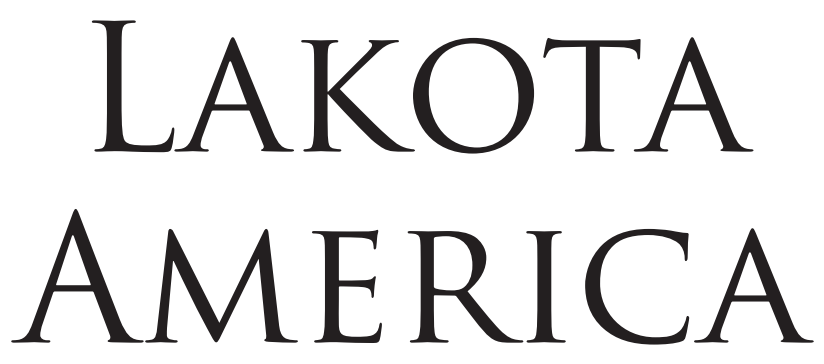

A New History of Indigenous Power

Pekka Hämäläinen

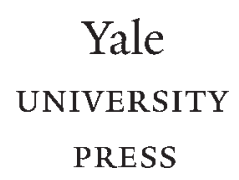

New Haven E London 
Published with assistance from the Annie Burr Lewis Fund.

Published with assistance from the Louis Stern Memorial Fund.

Published with assistance from the John R. Bockstoce Endowment Fund.

Endpapers: National Anthropological Archives, Smithsonian Institution; front: Flame winter count, 1887 , NAA INV o8633800;

back: Tracing of The Swan winter count, 1870, NAA INV o8633900.

Copyright @ 2019 by Pekka Hämäläinen. All rights reserved.

This book may not be reproduced, in whole or in part, including

illustrations, in any form (beyond that copying permitted by

Sections 107 and 108 of the U.S. Copyright Law and except by reviewers for the public press), without written permission from the publishers.

Yale University Press books may be purchased in quantity for educational, business, or promotional use. For information, please e-mail sales.press@yale.edu

(U.S. office) or sales@yaleup.co.uk (U.K. office).

Set in Electra type by Tseng Information Systems, Inc., Durham, North Carolina.

Printed in the United States of America.

Library of Congress Control Number: 2018966994 ISBN 978-0-300-21595-3 (hardcover : alk. paper)

A catalogue record for this book is available from the British Library.

This paper meets the requirements of ANSI/NISO Z39.48-1992 (Permanence of Paper).

1098766543221 